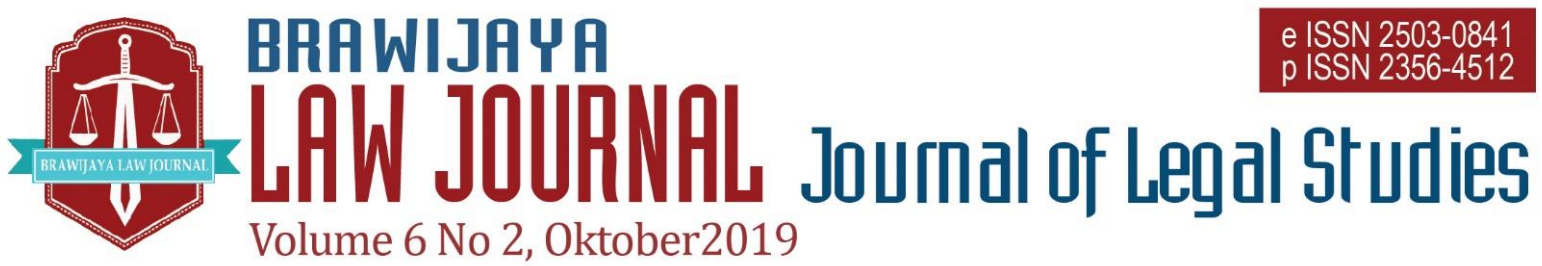

Nationally Accredited No. 30/E/KPT/2018 Dated 24th October 2018

This work is licensed under a Creative Commons Attribution-NonCommercial 4.0 International License

\title{
Access to Justice through Legal Aid in Nigeria: An Exposition on Some Salient Features of the Legal Aid Act
}

\author{
Akintunde Abidemi Adebayo ${ }^{a}$, Anthonia Omosefe Ugowe ${ }^{b}$ \\ ${ }^{a}$ Faculty of Law, Adekunle Ajasin University, Akungba-Akoko \\ Email: akintunde_adebayo@yahoo.co.uk \\ ${ }^{\mathrm{b}}$ University of Dundee, UK \\ Email: anthonia_ugo@yahoo.com (or) ugowe.ao@unilorin.edu.ng
}

Submitted : 2019-03-01 | Accepted : 2019-10-08

\begin{abstract}
According to Black's Law Dictionary, justice is the fair and proper administration of law. Similarly, access to justice is the ability to make use of the courts and other relevant institutions to efficiently protect and enforce rights. Access to justice is imperative in every society. People will access justice only if the proper situation creates. In a bid, to remove this major barrier in accessing justice, the Legal Aid Council of Nigeria was established in 1976. The concept of legal aid means the provision of free legal services to the indigent and underprivileged members of the society. Its importance and cannot be overemphasized particularly considering the level of illiteracy and poverty which are considered on the high side in Nigeria. Hence, in 2011, the Legal Aid Act 2011 was enacted. The birth of the Act repealed the old Act. This article analyses 3ethe provisions of both Acts with emphasis on the innovations of the new Act to promote access to justice and concludes with recommendations. Concerning the Council, it finds that there is a need for better funding and engagement of more salaried lawyers in order to enable it to carry out its functions as the Council is grappling with the challenge of underfunding and recruitment of more hands to work towards the achievement of its set objectives, among others.
\end{abstract}

Keywords: access to justice; justice; legal aid council; indigents; pro bono.

\section{INTRODUCTION}

"Justice is a human need while access to justice is a human right." 1 According to Black's Law Dictionary, justice is the fair and proper administration of laws. ${ }^{2}$ In the

1 C.O. Oba, 'Third Party Litigation Funding and Access to Civil Litigation: Prospects and Challenges in Nigeria' (2013) 23(2) African Journal Of Clinical Legal Education And Access To Justice. same vein, access to justice entails the use of courts and other legal institutions in the protection of rights and the pursuance of claims of members of society. ${ }^{3}$ As human beings interact with one another, there are

2 B.A. Garner (ed.), Black's Law Dictionary $\left(9^{\text {th }}\right.$ Edn.) (Thompson-West, New York), 942, 2009.

3 E. Wanyama, 'Unpacking the Dialectics of Accessing Justice through Legal Aid in East Africa: An Overview of the Constitutions of Uganda and Kenya' (2013) 59(2) African Journal 
bound to be disputes and conflicts. Sometimes, conflicts may deteriorate to the extent of the persons or one person approaching the courts to file legal actions. Other times, conflicts may be resolved amicably without recourse to the court of law. Still, the fact remains that access to justice would only be guaranteed in a society where people can enforce and protect their rights. ${ }^{4}$ It is a known fact that accessing justice by a vast majority of members of the society could be very difficult due to reasons such as ignorance, illiteracy, and lack of financial strength to pay for the services of a lawyer to either sue on their behalf or to defend them. ${ }^{5}$ Hence, the evolvement of the legal aid scheme in Nigeria. The primary aim of the scheme is the provision of pro bono legal services including litigation, legal advice, and alternative dispute resolution, among others to members of the society. ${ }^{6}$

\section{LEGAL MATERIALS AND METHODS}

This paper begins with a brief description of access to justice, history of the Legal Aid Council of Nigeria, the salient provisions of the repealed Legal Aid Act 1976 and the extant Act of 2011 on access to justice. It goes ahead to examine the operations of the Legal Aid Council in Nigeria particularly when it comes to the promotion of access to justice and provision of pro bono legal and quasi-legal services indigent members of the society access and

Of Clinical Legal Educastion And Access To Justice.

4 M.M Barry, 'Clinical Legal Education in the Law University: Goals and Challenges', (2007) International Journal Of Legal Education, pp 2750

$5 \quad$ Ibid.

6 Legal Aid Council of Nigeria, (2 July 2019), <http://www.legalaidcouncil.gov.ng> based on the conclusion, useful suggestions were made.

\section{RESULTS AND DISCUSSION}

\section{Brief History and Operation of the Legal} Aid Council of Nigeria (LAC)

The concept of legal aid in Nigeria dates back to around 1961 when the then Chief Justice of Nigeria, Adetokunbo Ademola observed the inadequacy of the right to a fair hearing. He observed the plenary of the Africa Conference on the Rule of Law in Lagos, Nigeria. ${ }^{7}$ Subsequently, a Bill titled 'Legal Aid and Advice Act 1961' was sponsored by T.O Elias, the AttorneyGeneral at the time was for the establishment of legal aid in Nigeria. ${ }^{8}$ The primary aim of the Bill was to establish a government agency that will be saddled with the responsibility of providing legal aid to low-income earners who ordinarily cannot pay for the services of a lawyer for the pursuance of a legitimate claim, protection of their rights or obtaining of a relief. The passing of the Bill into law was truncated by the Nigerian civil war from 1967 to $1970 .^{9}$

After the war, the establishment of the Nigerian Legal Aid Association (NLAA) took place on the 6th of February 1974.10 The Association consisted of lawyers concerned about providing legal aid to poor Nigerians. ${ }^{11}$ Subsequently, branches of the association sprang up in states like Lagos, Plateau, Oyo and Cross Rivers. ${ }^{12}$

The association enjoyed support and cooperation from the Bench at both the

7 A historical Profile of the Legal Aid Council of Nigeria, (14 February 2019), <http://www.legalaidcouncil.gov.ng/index.php/en /about-us/profile.>

8 Ibid.

9 Ibid.

10 Ibid.

11 Ibid.

12 Ibid.

142 | Adebayo, Oguwe - Access to Justice through Legal Aid in Nigeria... 
national level as well as state branches level. Of particular note was the support of important jurists like Mohammed Bello, T.O Elias, G.S Sowemimo, M.O Balonwu, Ayo Irikefe, Dan Ibekwe, and S.M.A Belgore. ${ }^{13}$ Over time, the efforts and activities of the association led to the promulgation of the Legal Aid Decree or Legal Aid Act no. 56 of 1976 on 10th November 1976. ${ }^{14}$ It is important to state that the birth of this Decree marked the formal introduction of the legal aid scheme in Nigeria. ${ }^{15}$

According to section 19 (1) of the Act, the Legal Aid Act was to come into force on such a day as the Attorney-General may, by order appoint. ${ }^{16}$ Consequently, Augustine Nnamani who was then the Attorney General of the Federation ordered the Legal Aid Act into force, on the 2nd May 1977. Therefore, the first Legal Aid Council (hereinafter referred to as the Council) was established by with the provisions of the Legal Aid Act. ${ }^{17}$

It can, therefore, be said that the sole reason for the establishment of the Legal Aid Council was to avail the underprivileged and indigent persons in the society in need of legal assistance and could not afford it, pro bono legal service. Of particular interest were: women; children; elderly persons; persons with disabilities, among others. Most of these persons live in biting poverty and are extremely vulnerable to human rights abuses. ${ }^{18}$ This article appraises the repealed Legal Aid Act of 1976 and the new Act of $2011^{19}$ vis-à-vis access to justice through the Council in Nigeria.

\section{The Legal Aid Act of 1976}

The 1976 Act provided for the establishment of the Legal Aid Council in section 1. It went further by for the composition of the Governing Board of the Council. ${ }^{20}$ The membership of the Board consisted of a chairman who was appointed by the President of the Federal Republic and fourteen (14) members namely, the Representative of the Attorney General of the Federation, the Representative of the Federal Ministry of Finance, the Representative of the National Youth Service Corp and the Representative of the Inspector General of Police. ${ }^{21}$ Also, it had four (4) representatives of the Nigerian Bar Association, the Director-General of the Legal Aid Council and five (5) other persons to be appointed by the President of the Federal Republic of Nigeria to represent various other interests. ${ }^{22}$ The chairman of the board was to hold office for three (3) years and the appointment shall be subject to renewal for another three (3) years period. ${ }^{23}$ Similarly, other members of the Board shall also hold their office for three (3) years and the appointment shall be renewable for a further three (3) years period. ${ }^{24}$

The Director-General of the Council shall be appointed by the President of the Federal Republic on the recommendation of the Attorney General of the Federation. ${ }^{25}$ The Director-General shall be saddled mainly with the responsibility of running the everyday affairs of the Council and the person shall be a legal practitioner of at least

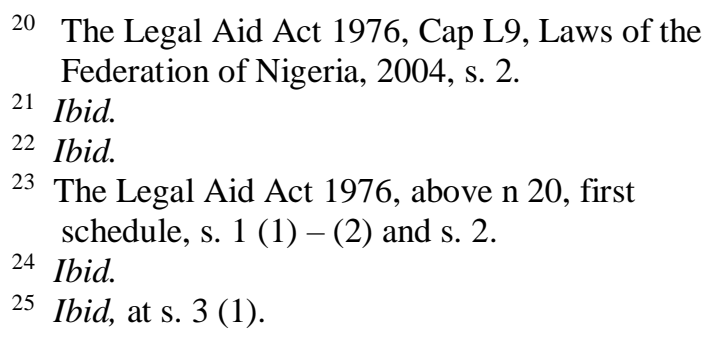

13 Ibid

14 Ibid.

15 Ibid.

16 Ibid.

17 Ibid.

18 Wanyama, above n. 3, at 59-72.

19 The Legal Aid Act 2011. 
ten (10) years standing. ${ }^{26}$ In the same vein, to ease the operation of the Council, it was empowered to appoint other legal and nonlegal supporting staff to work in the Council nationwide and their appointment was subject to the conditions of service in the Federal Civil Service Commission. ${ }^{27}$

Also important is the pension ability of service in the Council. Therefore, the Director-General and other members of staff of the Council were entitled to pensions, gratuities and other retirement benefits as enjoyed by other persons in public service in the country. ${ }^{28}$

In the bid to make the services of the Council accessible to persons at the grassroots, the Act provided for the establishment of state offices, subject to the approval of the President of the Federal Republic $^{29}$

The areas of coverage of legal aid services included both criminal and civil matters and stated in the second schedule to the Act thus: a. Murder (also known as culpable homicide, punishable with death); b. Manslaughter (also known as culpable homicide, not punishable with death); c. Malicious or willful bodily harm; d. Assault occasioning actual bodily harm and common assault. Others are affray, rape, and stealing. ${ }^{30}$ For civil matters, they were civil claims in respect of accidents and civil claims in respect of fundamental human rights enforcement $^{31}$

For the funding of the Council, the Act provided for the Legal Aid Fund. ${ }^{32}$ The fund received regular payments from the federal and state governments. ${ }^{33}$ In addition to that, it also received monies by way of contributions under the Act as well as gifts and testamentary dispositions from philanthropic organizations and individuals. ${ }^{34}$ However, the Council prohibited from accepting gifts from any organizations or individuals with conditions inconsistent with the objectives of the Council. ${ }^{35}$

In the area of entitlement and access to legal aid, the 1976 Act provided that legal aid shall be granted to a person whose income does not exceed N5, 000.00 (five thousand naira) per annum. ${ }^{36}$ However, subject to the regulation and approval of the President of the Federal Republic, it might also be granted on a contributory basis to an individual whose income exceeded N 5,000.00 (five thousand naira) per annum. ${ }^{37}$ Also, the rules of courts on payment of fees and costs did not apply to anyone granted legal aid. ${ }^{38}$ In ascertaining the means of applicants for grant of legal aid, the Council considered income, personal and real properties. ${ }^{39}$

The Council also made use of private legal practitioners in the discharge of its duties. ${ }^{40}$ The concerned practitioners were registered with the Council and constituted into different panels which shall be for diverse specific purposes. $^{41}$ In situations where the services of a legal practitioner were not gratuitous, the legal practitioner was paid from the Legal Aid Fund and no payment was to be taken from the person granted legal aid. ${ }^{42}$ Similarly, the Council

\footnotetext{
35 Ibid, at s. 11.

$36 \mathrm{Ibid}$, at s. 9 (1).

37 Ibid, at s. 9 (2).

38 Ibid, at s. 9 (4) and (5).

39 Ibid, at s. 9.

40 Ibid, at s. 13.

41 Ibid.

42 Ibid.
} 
also made use of legal practitioners undertaking the compulsory National Youth Service Corp for its services. ${ }^{43}$ The services of such young legal practitioners were free and no payment made by the Council to them. ${ }^{44}$ The penalty for giving of false information in order to receive legal aid was N200 (two hundred naira) fine or imprisonment for a maximum period of six (6) months or both. ${ }^{45}$

For the sake of accountability and to be able to adequately measure the productivity of the Council, the 1976 Act provided for the rendering of the annual report to the President of the Federal Republic through the Attorney-General of the Federation. ${ }^{46}$ The Attorney-General made regulations for the proper carrying out of the functions of the Council. $^{47}$

\section{The Legal Aid Act of 2011}

In 2011, the Legal Aid Act was amended. The amendment repealed the old Act, which is, the Legal Aid Act, and Cap.L9 Laws of the Federation of Nigeria 2004.

According to section 1 (1) of the new Act, the Legal Aid Council was established to provide legal aid and access to justice to the less privileged members of the society. ${ }^{48}$ The Council is a body corporate with the ability to sue and be sued. The Council has a responsibility to provide access to justice, legal aid and advice. It comprises of the Governing Board that is, the Chairman and members; the Director-General as well as other members of staff (legal and nonlegal). ${ }^{49}$

Also, the qualification and membership of the Governing Board as provided for in the new Act. The Chairman of the Governing Board who shall be appointed by the President must be either a Judicial Officer who is retired or a lawyer of repute with not less than 15 years standing. ${ }^{50}$ Other members of the board shall be sixteen (16) in number. There are three (3) major departments at the Council's head office, namely: Finance and Administrative Department, Litigation Department and International Relations, Corporate Operations, Planning, and Research. The new Act, however, empowers the Council to create more departments as the Governing Board may decide. ${ }^{51}$

In a bid to make justice more accessible to indigent members of the Nigerian society, the new Act for the first time provided for the establishment of zonal offices in each geopolitical zone of the country. The zonal office is headed by an officer who coordinates the state offices in the zone. ${ }^{52}$ The Zonal Officer is responsible to the Director of Litigation. ${ }^{53}$ The Council has a presence in each state in the country and state offices are coordinated by an officer who is responsible for activities in the state. The state coordinators report to the zonal officer in charge of such a state. The three legal services units of the Council are operated in the state offices, that is, Criminal Defense; Civil Litigation and Community Legal Service. ${ }^{54}$ However, there is the need for a better geographical spread of the offices of the Council to make justice more accessible to the doorstep of the indigents. For instance, in some states, the office of the Council is only located in the capital while persons in the hinterlands and other remote areas of the state who may not have the

49 Ibid, at s. (2) - (4).

$50 \mathrm{Ibid}$, at s. 2 (1) and (2).

51 Ibid, at s. 6 (1) (a) - (c).

52 Ibid, at s. $6(2)$.

53 Ibid, at s. 6 (3).

54 Ibid, at s. 6 (4) and (5). 
wherewithal to get to the capital will be denied access to justice.

According to section 46 of the Constitution of the Federal Republic of Nigeria, the Council is funded mainly by the Federal Government of Nigeria through funds appropriated annually by the National Assembly. ${ }^{55}$ In addition to that, there are also funds allocated to legal aid as well as access to justice by states of the Federation, including the Federal Capital Territory. It can also accept donations from individuals and bodies apart from the general funds allocated. ${ }^{56}$ However, it has been observed that the funds appropriated by the National Assembly have been grossly inadequate to effectively fund the operations of the Council. $^{57}$

Every state is obliged to ensure access to justice by its citizens, without any hindrance or barriers. ${ }^{58}$ To achieve this, states must ensure that the major barrier to access justice, that are legal fees or financial weakness is removed by providing legal aid to the less privileged and downtrodden in the society. ${ }^{59}$ It follows therefore that an efficient legal aid scheme is germane for unrestricted access to justice. ${ }^{60}$

Given this, every society must, therefore, provide its citizenry with pro bono legal service, particularly the vulnerable and poor members of the society. ${ }^{61}$ It is imperative to mention that the Nigerian

55 Nigerian Const. 1999 (as amended).

56 The Legal Aid Act 2011, above n 19, s. 9.

57 O. Gbolagunte, Refurbishment of Legal Aid in Nigeria, (22 August 2018), <http://davidsongbolagunte.wordpress.com/2014/ 07/08/refurbishment-of-legal-aid-in-nigeriagbolagunte-oladotun/>

58 E. Ojukwu, et. al, Access to Justice, Chapter 5, Handbook on Prison Pre-Trial Detainees for Law Clinics, (Network of University Legal Aid Institutions, Nigeria) 121-152, 2012.

59 Helen Obura, Facilitating Access to Justice through Legal Aid: Models, Laws and Practices in East Africa: a Case of Uganda, being paper government must be commended in this regard having established the Council as the primary agency saddled with such responsibility. ${ }^{62}$ The Council is empowered to provide legal aid and access to justice in three areas namely: Criminal Defence Service; Civil Litigation Service as well as advice and assistance in Community Legal Services, provided the persons concerned are indigents. Under the Criminal Defence Service, the Council shall be responsible for assistance to indigents involved in a criminal investigation, representation or advice. ${ }^{63}$ Criminal offenses which fall within the scope of the Council as listed in the second schedule of the new Act are: murder; manslaughter; malicious or grievous hurt; assault occasioning bodily harm; common assault and affray. Others are stealing; rape, armed robbery and aiding and abetting the commission of any of the afore-listed offences. $^{64}$

The Civil Litigation Service shall assist the indigents in accessing justice, legal advice, representations in courts/tribunals for the purpose their defense; enforcement and protection of their rights, obligations and interests as guaranteed by the laws of the land. ${ }^{65}$ The scope of the responsibilities of the Council when it comes to civil litigation service are: civil claims in respect of accidents including employee's compensation claim; claim covering breach

presented at the $8^{\text {th }}$ East African Judicial Conference held at Arusha, Tanzania, at 3, 2009.

60 N. Ojukwu-Ogba, Criminal Justice Administration and Fundamental Rights Protection in Nigeria: The Legal Aid Act 2011 in Perspective in Issues on Criminal Justice Administration in Nigeria, Edited by Adekunle Adedeji, et.al (Nigerian Institute of Advanced Legal Studies, Lagos) 90-97, 2016.

61 Ibid.

62 Legal Aid Act 2011, above n. 19, s. 8.

63 Ibid, at s. 8 (2).

64 Ibid, at second schedule.

65 Ibid, at s. 8 (3) and (4). 
of fundamental rights under the Constitution of the Federal Republic of Nigeria, 1999 and civil claims arising from criminal activities against a person who is qualified for legal aid under the new Act. Also, the Council runs the Community Legal Service which is mainly involved in the provision of legal assistance, resolving disputes about legal rights and duties. $^{66}$ It is important to note that in the exercise of the Community Legal Service, the Council shall ensure that there is a swift and fair resolution of disputes and access to justice. ${ }^{67}$

It is estimated that the Council handles averagely 25,000 cases (both criminal and civil) annually for indigent Nigerians. ${ }^{68}$ It is imperative to state that this is commendable. ${ }^{69}$ However, considering the size of the Nigerian population which is almost 200 million with a vast majority considered indigent, the Council handling an average of 25, 000 cases annually is not good enough, a lot more still needs to be done.

According to the new Act, legal aid shall be provided to persons who do not earn up to the national minimum wage, which is currently eighteen thousand naira (N18, 000.00). Considering the present-day economic reality and inflation, so many people who earn more than the national minimum wage are yet impoverished. Therefore, the requirement of the national minimum wage as a qualification for legal aid may cause hardship and prevent so many Nigerians from accessing justice. However,

$66 \mathrm{Ibid}$, at s. 8 (7).

67 Ibid, at s. 8 (8).

68 A.I Abdulkadir, Legal Aid Council at 40, Blueprint News, Nigeria (22 August 2018), $<$ https://www.blueprint.ng/legal-aid-council-ofnigeria-40/>

69 M. Egbejule And I. Akpan-Nsoh, Legal Aid Council Settles 174 Cases in Edo and Akwa Ibom, Guardian Newspaper, Nigeria of 22 March 2016 $(22$

August

2018), in a bid to further enhance access to justice for members of the society, legal aid may be granted on a contributory basis to persons whose earning exceeds the national minimum wage up to ten times provided the Governing Board approves same. ${ }^{70}$ While it is a good thing that the Council can grant legal aid to persons earning above the national minimum wage, it is important to state that not every person whose earning is above the national minimum wage would be able to benefit from this because of the proviso that it must be on contributory basis, as they may not find this affordable. Again, it will take the Board to approve such an application for legal aid for persons who earn above the national minimum wage and this could be very cumbersome and timeconsuming. There should be no restriction whatsoever, no requirements fixed for access to legal aid by all Nigerians. ${ }^{71}$ It is important to state that the new Act, however, exempts corporate bodies from accessing legal aid. Similarly, the rules of any court relating to the payment of fees shall be waived a person who is benefitting from legal aid. ${ }^{72}$ What this means is that the Council shall not pay for costs awarded in the course of a legal proceeding against a person who is a beneficiary of legal aid. Similarly, the rules of court relating to the payment of fees, including but not limited to filing fees shall not apply to a person who has been granted legal aid. However, due to high level of corruption in the country, officials in the 
court registry where cases are to be filed and the bailiffs who are supposed to serve the filed processes on the appropriate parties are in the habit of demanding for money as 'tip' before they carry out their lawful duties. ${ }^{73}$ Whenever their demands are not met by legal practitioners working for the Council, they frustrate the cases either by delaying the assignment of such cases to courts/judges or by not effecting service on the necessary parties. ${ }^{74}$ This may consequently cause a delay in the dispensation of justice.

Register of legal practitioners who represent indigent persons that are qualified for legal aid are maintained by the Council. Given this, private lawyers who are desirous of rendering pro bono legal services to the less privileged and downtrodden in the society are encouraged to register with the Council. This will enable the Council to track and monitor the progress of cases being handled by such lawyers. Also, it is now part of the requirements to be conferred with the prestigious rank of Senior Advocate of Nigeria that aspirants must have diligently conducted not less than three (3) cases on pro bono basis in the legal year preceding the making of the application. ${ }^{75}$ It has however been observed that most of the senior lawyers in Nigeria are not honestly committed to giving back to their various communities and impacting positively on the lives of indigent members of the society through engaging in pro bono services. They simply do so to fulfil the requirement that they must conduct at least three cases of pro bono before they can be conferred with the rank of Senior Advocate of Nigeria. ${ }^{76}$ This attitude is

73 R. Otaru, Access to Justice and Right to Fair Hearing, 35-36, Pdf file (23 August 2018), <http://www.otaruotaru.com>

74 Ibid.

75 Legal Aid Act 2011, above n. 19, s. 18 (2).

76 Agbamuche-Mbu, above $\mathrm{n} 71$. condemnable and has not assisted much in the Council's objective of promoting access to justice. Apart from the requirement of aspiring lawyers to the prestigious rank of Senior Advocate of Nigeria engaging in three cases pro bono in the year preceding their application, the Council has partnered with about Three hundred and forty-three (343) law firms toward the provision of access to justice to indigent members of the society. ${ }^{77}$ It must be said that in spite of this laudable initiative, a very huge Nigerian population, particularly the poor still cannot access justice through the Council. So many poor and vulnerable persons are still detained unjustly in police cells, prisons congested, and dispensation of justice delayed as a result of inadequate legal representation, among others. $^{78}$

Closely related to the aforementioned is the use of National Youth Service Corp members who are legal practitioners working with the Council to give legal aid and access to justice to indigent members of the society. To further encourage and spur such corps members to be committed, the Council pays a stipend to cover their transportation in the course of rendering their services. ${ }^{79}$ While commending this innovation, it must be mentioned that considering the present economic reality and inflation in the country, the stipend paid by the Council to the corps members may be a major discouragement to their commitment to the services of the Council. The stipend compared to the distance they may have to cover and the huge workload may not be sufficient to get

${ }^{77}$ U. Ukpong, Poor Nigerians Lack Access to Justice - Legal Aid Council, Nigerian Pilot Newspaper of 22 July 2017 (22 August 2018), $<$ http://nigerianpilot.com/poor-nigerians-lackaccess-to-justice-legal-aid-council/>

78 Ibid.

79 Legal Aid Act 2011, above n. 19, s. 16. 
anything done. ${ }^{80}$ To make matters worse, the money may not even be paid as and when due and these corps members may have to resort to spending from their purses to fund their services for the Council. ${ }^{81}$ The irregular payment of stipend to these corps members has been blamed on the paucity of funds from the government. ${ }^{82}$ The problem of inadequate funding is a major one. It is attributed to the fact that no precise amount is allocated to the Council, its funding is subject to whatever the National Assembly appropriates to it. ${ }^{83}$ The reality is that the National Assembly has never deemed the issue of promoting access to justice for Nigerians particularly the indigent ones so important, therefore, less priority given to it in the scheme of things and appropriation of funds. ${ }^{84}$

Non-governmental organisations and university-based law clinics under the Network of University Legal Aid Institutions (NULAI) have continued to play vital roles in the rendering of pro bono legal services to indigent members of the Nigerian society and promoting access to justice. ${ }^{85}$ Some of their activities include providing amicable resolution of civil disputes, providing counselling services, regular prison visits and facilitating the release of pre-trial detainees, securing the release of detainees at police stations as well as representing clients in both criminal and civil cases before courts and tribunals.

In order to properly appraise the partnership of the Council with these organisations and promote access to justice,

80 Gbolagunte, above n. 57.

Ibid.

82 Ibid.

83 Ibid.

84 Ibid.

85 OJUKWU et.al., Clinical Legal Education Curriculum Lessons and Materials (Network of University Legal Aid Institutions (NULAI), Abuja, 4-9, 2013. the Council maintains a register where the details of such organisations and law clinics who are engaged in the provision of pro bono services and assistance to persons who are entitled to legal aid as well as their activities are recorded. ${ }^{86}$ It has been observed that the collaboration between the Council and these NULAI law clinics have only existed on the papers and not in reality. The Council has not been pro-active in its collaborations with these law clinics. Most of these clinics have not received any form of support or encouragement from the Council, neither have their activities been monitored to ensure effectiveness nor fulfilment of their set mandates.

In order to check the ever-increasing population of detainees at the police stations and prison facilities across the country, the Council is enjoined to rregularly visit prisons, police stations as well as other places where suspects are kept to review the circumstances surrounding their detention. ${ }^{87}$ To further promote access to justice, the Council has made provision for early access to legal advice and representation. ${ }^{88}$ It, therefore, prevails on police officers and courts to inform suspects of their entitlement to the services of a lawyer of their choice right from the moment of arrest and where the suspects are incapable of securing the services of a private lawyer, the Council must be notified so that the suspects can be represented by the Council if they so wish. ${ }^{89}$ The Council in conjunction with Open Society Justice Initiative and the Nigerian

\footnotetext{
86 Legal Aid Act 2011, above n 19, s. 17.

87 Ibid, s. 19 (1). See also S. Ibe, 'Arresting Escalating Pre-Trial Detention in Nigeria: Some Reform Ideas' (2013) 2 African Journal of Clinical Legal Education and Access to Justice, 102-104.

88 Ibid.

89 Legal Aid Act 2011, above n 19, s. 19 (2).
} 
Police Authority also have in place an arrangement known as 'Police Duty Solicitors Scheme' whereby legal practitioners, as well as lawyers under the National Youth Service Corp Working for the Council, are deployed to police stations to grant legal aid, in form of legal advice and representation to indigent criminal suspects within the first 48 hours of arrest. ${ }^{90}$ These lawyers are, therefore, granted unrestricted access to detainees in police cells, prisons and other places. ${ }^{91}$ They will also be entitled to conduct interviews or be present during the interrogation of suspects under the provisions of the 1999 Constitution of the Federal Republic of Nigeria (as amended) ${ }^{92}$ It is pertinent to state that in reality, the Council has not done too well in carrying out these objectives. The major constraints against the fulfilment of those objectives are the inadequacy of personnel and inadequate funding. ${ }^{93}$ For the Council to visit police stations and prisons regularly to review the cases of detained persons, it must be adequately funded, there must be functional vehicles to convey lawyers to ease their movement and there must be adequate personnel on the ground to carry out the assignment. ${ }^{94}$ According to the immediate past Director-General of the Council, Joy Bob-Manuel, she noted that the salaried lawyers in the Council were inadequate to attend to the needs of the Nigerian population which stood at that time at 170 million people and this has consequently resulted in defendants waiting endlessly for the resolution of their cases due to inadequate

90 Ibe, above n 87, at 115-116.

91 Ibid.

92 Legal Aid Act 2011, above n 19, s. 19 (3).

93 Gbolagunte, above n. 57; Ukpong, above n. 77.

94 Ibid.

95 Ukpong, above n. 77.

96 C. Ayansina, Laws in Nigeria are Against the Poor

- Legal Aid Council, Vanguard Newspaper, legal representation. ${ }^{95}$ In another forum, the Bob-Manuel was equally quoted to have revealed that it has been extremely difficult for the Council to fulfil its mandate and adequately defend indigent persons in Nigeria with only four lawyers per state. ${ }^{96}$ As a matter of fact, in some state offices of the Council, there are less than four lawyers. The question then will be how less than two lawyers can be effective in a whole state.

However, the Council regularly collaborate with the Judiciary, Office of the Attorney-General of the Federation or of any State, the Department of Public Prosecution, the Inspector-General of Police, the Commissioners of Police, Prison Authority or other agencies as may be appropriate, in order to ensure quick dispensation of justice for the less privileged and downtrodden persons they represent. ${ }^{97}$ In the same vein, the Council as part of its mandates regularly makes an application in appropriate courts for the review of cases of persons who have been held in any place of custody without trial over the maximum time provided by the Constitution. This privilege is however not limited to persons who are entitled to legal aid alone. ${ }^{98}$ To a large extent, the Council has made an impact in this regard. However, a lot still needs to be done. As mentioned earlier, the problem of inadequacy of personnel and fund have constituted major challenges in achieving these objectives. ${ }^{99}$

\section{Some of the Innovations and new features of the Legal Aid Act 2011 and Access to Justice}

Nigeria of 8 August 2015, (22 August 2018), $<$ http://www.vanguardngr.com/2015/08/laws-innigeria-are-against-the-poor-legal-aid-council/>

97 Legal Aid Act 2011, above n 19, s. 19 (4).

$98 \mathrm{Ibid}$, at s. 19 (5).

99 Gbolagunte, above n 57. See also Ojukwu-Ogba, above $\mathrm{n} 60$, at 100-103. 
a. To ensure adequate representation of interests on the Governing Board of the Council, the membership of the Governing Board increased from thirteen (13) to sixteen (16). ${ }^{100}$

b. The Director-General shall now enjoy tenure of four (4) years and shall be renewable subject to satisfactory performance for another four (4) years. This is in line with what obtains in the Federal Civil Service where Directors and Permanent Secretaries now can only spend a maximum of eight (8) years in those capacities. ${ }^{101}$ This is to afford the Director-General adequate time to efficiently attend to the affairs and management of the Council without any hindrance or disruptions, which could be occasioned by the time constraint.

c. The responsibility of the DirectorGeneral has been upgraded under the 2011 Act to the day-to-day management of the resources of the Council such as, human, financial and material unlike what was obtainable under the previous Acts. ${ }^{102}$ This would invariably influence the activities of the Council towards achieving its set objectives.

d. Section 4 (4) of the 2011 Act now empowers the Council to recruit, employ personnel both legal and non-legal (including permanent and contractbased) as may be required for the smooth running of the Council and implementation of its objectives. This autonomy will go a long way to address the problem of inadequate manpower which before the amendment of the Act was a clog in the wheel of progress of the

\footnotetext{
100 Legal Aid Act 2011, above n 19, s. 2 (1) (g) - (k).

$101 \mathrm{Ibid}$, at first schedule.

102 Ibid, at s. 4 (1).

103 Legal Aid Act 2011, above n 19, at second schedule.
}

Council. The Council can now recruit officers at will, based on the needs and financial strength of the Council. However, despite this provision, the problem of shortage of manpower has continued to plague the Council. This is largely due to poor wage rate and poor conditions of service.

e. The scope of the Council concerning entertaining criminal matters as listed in the Second Schedule to the 2011 Act was increased. ${ }^{103}$ The Council now has scope to entertain criminal matters such as murder (also known as culpable homicide punishable with death), manslaughter (also known as culpable homicide not punishable with death) and malicious or willful grievous hurt (also known as wounding or inflicting grievous bodily harm). Others are, assault occasioning actual bodily harm (also known as criminal force occasioning actual bodily harm), common assault, affray, stealing, rape and armed robbery. ${ }^{104}$ It is pertinent to note that despite the expansion of the scope of the Council concerning criminal trials, many indigents persons are still languishing in prisons and police cells across the country without any legal representation, consequently, the prisons are still congested mostly by awaiting trial inmates. As of $3^{\text {rd }}$ December 2018, the total population of Nigerian prisons was 75,772 . Out of this figure, 24, 388 (32\%) were convicts while 51, 384 $(68 \%)$ were awaiting trial inmates. ${ }^{105}$

f. The scope of the Council's involvement in civil matters became expanded by the

\footnotetext{
104 Ojukwu-Ogba, above n. 60, at 97.

105 Summary of Prison Population, (14 February 2019), <http://www.prisons.gov.ng/statistics>
} 
provision of Section 8 (3) and (4) of the 2011 Act. The Council now entertains civil matters in the following areas: claims arising from accident under Employee's Compensations Claim (pursuant to the Employee's Compensations Act, No. 13 of 2010); claims arising from the breach of fundamental human rights and lastly, claims arising from criminal activities against persons who are qualified for legal aid.

It is important to state that the Council has entertained a considerable number of civil cases for indigent members of the Nigerian society since 2011 when its scope on civil matters was expanded.

g. The Act provides for two main sources of funds for the operations of the Council, that is, funds appropriated by the National Assembly and funds budgeted by the states of the federation including the Federal Capital Territory. ${ }^{106}$ In addition to the aforementioned, the Act also separately empowers the Council to accept donations, gifts and other related things but not as part of the general funds for the Council. ${ }^{107}$ It is imperative to note that despite the provision for funding, the Council is still considered underfunded and this has adversely affected the fulfilment of its objectives. $^{108}$

h. The Council is to maintain a register of non-governmental Organisations and law clinics that are involved in the provision of free legal services to

${ }^{106}$ Ibid. See also Legal Aid Act 2011, above n 19, s. 9.

107 Legal Aid Act 2011, aboven 19 , s. 12.

108 Legal Aid Council Receives 18 Cases in 2 Months in Kano, (17 February 2019), $<$ http://www.legalaidcouncil.gov.ng/index.php/en /> individuals who are qualified for such under the Act. ${ }^{109}$ This is to aid the Council in proper planning, efficient monitoring and implementation of its objectives. This will consequently increase access to justice.

i. The Act provides that legal aid shall be provided to persons whose income is below the national minimum wage. It further provides that the Governing Board could, however, grant legal aid on a contributory basis to persons whose earning exceeds the national minimum wage up to ten times. This is an improvement on the earlier provision of the old Act which provided that legal aid would only be granted to persons whose income do not exceed five thousand naira (N5, 000.00) per annum except with the approval of the President of the Federal Republic. ${ }^{110}$

j. The Act empowers the Council to collaborate with non-governmental organisations or law clinics by the mandate of the Council. ${ }^{111}$

k. National Youth Service Corp members who are legal practitioners with the Council can now get a stipend for transportation in the course of working for the Council. ${ }^{112}$ This is against what was obtainable in the old Act. This will go a long way to spur such corps members while performing their duties in the service of the Council.

1. The Council is empowered to give licenses to persons who have been trained to be paralegals in order to render such services when required. ${ }^{113}$ This will

\footnotetext{
${ }^{109}$ Legal Aid Act 2011, above n 19.

${ }^{110} \mathrm{Ibid}$, at s. 10.

111 Ibid, at s. 17 (2).

$112 \mathrm{Ibid}$, at s. 14.

113 Ibid, at s. 17 (3).
} 
help to reduce the burden and pressure on the legal practitioners and officers of the Council and by implication reduce the workload of the Council.

$\mathrm{m}$. The Council is empowered to carry out regular inspection of police cells, prisons and other places where suspects are detained to review the circumstances surrounding their detention. ${ }^{114}$ This innovation is a laudable one as it will check the rate at which police detain suspects arbitrarily and help to decongest police cells as well as prison facilities across the country.

n. There shall be a regular collaboration between the Council, judiciary, Attorney-General of the Federation or State (as the case may be) and the Department of Public Prosecution. Also, the Inspector General of Police, Nigerian Prison Authority and other appropriate agencies to enhance quick dispensation of justice. ${ }^{115}$ This will greatly enhance access to justice in the country.

o. File an appropriate application for the release or review of cases of persons who have been detained without trial over the maximum period allowed by the Constitution. ${ }^{116}$ This could be by way of filling applications for bail, applying for striking out where the prosecution is not diligent in carrying out their duties or in any other way appropriate depending on the circumstances surrounding each case.

\section{CONCLUSIONS AND SUGGESTIONS}

Having highlighted the reason behind the establishment of the Legal Aid Council of Nigeria, the article studied the pillars

\footnotetext{
${ }^{114}$ Ibid, at s. 19 (1).
}

115 Ibid, at s. 19 (4). upholding both the old Act, that is, the 1976 Act (which is now repealed) and the extant Act, that is, the 2011 Act. The Legal Aid Act 2011 has no doubt introduced some laudable innovations and filled identified lacunas in the areas of functions, operation, responsibilities and duties of the Council. It is a great improvement on the old Act. However, a lot still needs to be done to make justice more accessible to the downtrodden and indigent members of our society. It must be borne in mind that having all the statutory provisions in place is not enough but a thorough implementation of these provisions and the commitment to the rule of law.

Based on the foregoing, it is therefore suggested thus: First, Stakeholders in the justice sector must at all times be committed and reminded of the duty to ensure that all, irrespective of status, background, ethnicity or religion get quick and unfettered access to justice. Second, Legal practitioners should appreciate and participate in the legal aid scheme either through financial donations or by engaging in pro bono legal services and thereby contributing their quotas to humanity. Where these are done, they will impact positively on the economic and social well-being of the society. Third, the government must also appropriate more funds to the Council to enable it to live up to its expectations as the Council is currently grappling with the challenge of underfunding. If the Council is properly funded, it will be able to fulfil its set objectives and promote access to justice. The Council should be funded from the consolidated revenue fund to ensure security and certainty of fund for the Council. Apart from that, governments at the state and local government levels should also be mandated

116 Ibid, at s. 19 (5). 
to fund the operation of the Council to sustain it. Fourth, Well-meaning individuals, agencies, local and international bodies must rise and support the Council through donations in various forms including but not limited to money, office buildings, training and retraining of staff, provision of official vehicles, among others. Fifth, The Council must recruit more hands, both legal practitioners, paralegal and support staff to work as a team and assiduously towards the achievement of its set objectives. On this, the Council must make efforts to improve on the welfare and funding of the agency to make it more attractive to lawyers out there who may be interested in joining the Council. Sixth, more importantly, the remuneration and allowances of members of staff of the Council must be upwardly reviewed and improved upon by appropriate government agency/department as what they currently receive is poor and capable of dampening their enthusiasm as well as commitment. If this is done, it will go a long way to encourage the salaried lawyers in the Council to be more committed and to put in their very best in the performance of their duties and consequently access to justice will be enhanced. Seventh, the laudable police duty solicitor scheme of the Council must be improved upon, reinforced and expanded to all parts of the Federation. If this is done, it will avail indigent criminal suspect's access to early legal advice and representation and invariably check unnecessary detention in police cells as well as prison congestion. Eighth, to make justice accessible to all and sundry, section 10 of the Act which provides for qualification for legal aid should be amended such that there will be no restriction whatsoever to every Nigerian citizen. Legal aid should be upgraded to the status of a fundamental human right in the Constitution. Ninth, The requirement of aspiring lawyers to the prestigious position of Senior Advocates of Nigeria engaging in not less than three (3) pro bono cases in the preceding year before the making of the application should be reviewed to not less than ten (10) pro bono cases. Also, the government should make it a requirement for persons aspiring to occupy or be promoted to certain legal professional positions to engage in a certain number of pro bono services to promote access to justice in Nigeria. Tenth, there is also the need to publicise the existence and operations of the Council as so many Nigerian are not aware of its existence and functions. This publicity should be regular, done in both English and the various local dialects in the various Nigerian communities and disseminated through the mass media. Lastly, another germane point is the need for orientation and re-orientation of members of the public on the powers and scope of operation of the Council. This is important, as the majority of these detainees do not believe that they could receive quality and efficient service from the Council since it is pro bono. They would therefore rather consider the services of a private legal practitioner, and where they are poor and cannot afford one, they would instead be quiet even in the face of abuse and flagrant violation of their rights. Similarly, some pretrial detainees in police cells and prison facilities who are standing trial in criminal cases in court find it somehow awkward and difficult to reconcile how the government will be prosecuting them and the same government will be providing them pro bono legal service for their defence. Therefore, they doubt the sincerity of the services of the Council. Given this, regular orientation should be considered for police cells and prison detainees. 


\section{REFERENCES}

\section{Book}

Garner, B.A. (ed.), Black's Law Dictionary (9th Edn.) (Thompson-West, New York), 942, 2009.

Ojukwu et.al., Clinical Legal Education

Curriculum Lessons and Materials (Network of University Legal Aid Institutions (NULAI), Abuja, 4-9, 2013.

Ojukwu, E., et. al, Access to Justice,

Chapter 5, Handbook on Prison PreTrial Detainees for Law Clinics, (Network of University Legal Aid Institutions, Nigeria) 121-152, 2012.

Ojukwu-Ogba, N., Criminal Justice Administration and Fundamental Rights Protection in Nigeria: The Legal Aid Act 2011 in Perspective in Issues on Criminal Justice Administration in Nigeria, Edited by Adekunle Adedeji, et.al (Nigerian Institute of Advanced Legal Studies, Lagos) 90-97, 2016.

\section{Article/Journal}

Barry, M.M, 'Clinical Legal Education in the Law University: Goals and Challenges', (2007) International Journal Of Legal Education, pp 27-50

Oba, C.O., 'Third Party Litigation Funding and Access to Civil Litigation: Prospects and Challenges in Nigeria' (2013) 23(2) African Journal Of Clinical Legal Education And Access To Justice.

Obura, Helen, 'Facilitating Access to Justice through Legal Aid: Models, Laws and Practices in East Africa: a Case of Uganda', (Paper presented at the 8th East African Judicial Conference held at Arusha, Tanzania, at 3, 2009)
Ibe, S., 'Arresting Escalating Pre-Trial Detention in Nigeria: Some Reform Ideas' (2013) 2 African Journal of Clinical Legal Education and Access to Justice, 102-104.

Wanyama, E., 'Unpacking the Dialectics of Accessing Justice through Legal Aid in East Africa: An Overview of the Constitutions of Uganda and Kenya' (2013) 59(2) African Journal Of Clinical Legal Education And Access To Justice.

Act

The Legal Aid Act 2011.

The Legal Aid Act 1976, Cap L9, Laws of the Federation of Nigeria, 2004

Nigerian Const. 1999 (as amended).

\section{Internet}

Abdulkadir, A.I, 'Legal Aid Council at 40, Blueprint News, Nigeria (22 August 2018), <https://www.blueprint.ng/legal-aidcouncil-of-nigeria-40/>

A historical Profile of the Legal Aid Council of Nigeria, (14 February 2019), $<$ http://www.legalaidcouncil.gov.ng/in dex.php/en/about-us/profile>

Ayansina, C., Laws in Nigeria are Against the Poor - Legal Aid Council, Vanguard Newspaper, Nigeria of 8 August 2015, (22 August 2018), <http://www.vanguardngr.com/2015/0 8/laws-in-nigeria-are-against-thepoor-legal-aid-council/>

Agbamuche-Mbu, M., et.al., Legal Aid Should be Elevated to the Level of Fundamental Right, This Day Newspaper, Nigeria of 10 May 2016 (22 August 2018), $<$ http://www.thisdaylive.com/index.ph p/2016/05/10/legal-aid-should-be- 
elevated-to-the-level-of-a-

fundamental-right/>

Egbejule, M. And I. Akpan-Nsoh, Legal Aid Council Settles 174 Cases in Edo and Akwa Ibom, Guardian Newspaper, Nigeria of 22 March 2016 (22 August 2018), $<$ https://guardian.ng/news/legal-aidcouncil-settles-174-criminal-cases-inedo-aibom/>

Gbolagunte, O., Refurbishment of Legal Aid in Nigeria, (22 August 2018), $<$ http://davidsongbolagunte.wordpress .com/2014/07/08/refurbishment-oflegal-aid-in-nigeria-gbolagunteoladotun/>

Legal Aid Council Receives 18 Cases in 2 Months in Kano, (17 February 2019), $<$ http://www.legalaidcouncil.gov.ng/in dex.php/en/>

Legal Aid Council of Nigeria, (2 July 2019), <http://www.legalaidcouncil.gov.ng.>

Otaru, R., Access to Justice and Right to

Fair Hearing, 35-36, Pdf file (23

August 2018), <http://www.otaruotaru.com>

Summary of Prison Population, (14

February 2019),

<http://www.prisons.gov.ng/statistics>

Ukpong, U., Poor Nigerians Lack Access to Justice - Legal Aid Council, Nigerian Pilot Newspaper of 22 July 2017 (22 August 2018), $<$ http://nigerianpilot.com/poornigerians-lack-access-to-justice-legalaid-council/> 